\title{
Singular Reference in Fictional Discourse?
}

\author{
Manuel García-Carpintero \\ Universitat de Barcelona
}

BIBLID [0873-626X (2019) 54; pp.143-177]

\begin{abstract}
Singular terms used in fictions for fictional characters raise well-known philosophical issues, explored in depth in the literature. But philosophers typically assume that names already in use to refer to "moderatesized specimens of dry goods" cause no special problem when occurring in fictions, behaving there as they ordinarily do in straightforward assertions. In this paper I continue a debate with Stacie Friend, arguing against this for the exceptionalist view that names of real entities in fictional discourse don't work there as they do in simple-sentence assertions, but rather as fictional names do.
\end{abstract}

\section{Keywords}

Fictional reference, empty names, fictional characters, fiction, reference.

\section{Introduction}

Singular terms used in fictions for fictional characters - 'fictional terms' henceforth in general, 'fictional names' in particular-like 'Pierre Bezukhov' in War and Peace — raise complex philosophical issues of which philosophers are aware. As a result, the topic has been extensively covered, and there is a profligacy of philosophical views on offer. ${ }^{1}$

In contrast, philosophers tend to assume that singular terms already in use to refer to Austin's "moderate-sized specimens of dry goods", names in particular, cause no special trouble when occurring in fictions, and behave there exactly as they ordinarily do in straightforward assertions. The topic is casually broached en passant in two

\footnotetext{
${ }^{1}$ García-Carpintero 2019a provides a survey of recent proposals, which I'll assume here; $\$ 2$ below partially overlaps with it. 
of the (in my estimate) most influential contemporary discussions of fictional terms:

A name in a story may refer to a real person, that is, really refer to a person. For example, we could have a fictional story about Napoleon. In that case there is no such fictional character as Napoleon; it is rather that a real person is being written about, here in fiction (Kripke 2013: 75).

In fiction we do sometimes use genuine proper names to pick out particular individuals and say something about them that is part of the make-believe ... this is how Tolstoy uses 'Napoleon' in War and Peace (Currie 1990: 148).

Currie (1990: 131) thinks that fictional names are not real names, which explains the contrastive 'genuine'. This is because he assumes an "object-dependence" view of names, on which they would lack meaning if they lacked a referent; he takes fictional names to be disguised definite descriptions instead. Currie (1990: 171) does think that they are real names in what he calls transfictive uses (as in 'Sherlock Holmes is smarter than Poirot'); but like Kripke (2013), he doesn't take them to behave there as in the fiction, but to refer instead to abstract entities related to the descriptions he takes them to be synonymous with in fictional uses: roles, functions that pick out in possible worlds in which they get values what such descriptions would.

Nonetheless, the behaviour of real names in fictions has received serious attention belying this offhand majority attitude. Some philosophers, including Friend (2000, this volume) and Kot'átko (2010), have provided compelling arguments for the just illustrated majority nonchalant take on the issue, the nonexceptionalist (NE) view (as I'll call it henceforth) that names of real entities in fictional discourse work exactly as they do in ordinary assertions. If we assume, as I will, a direct reference view on which they just contribute their referents and are therefore rigid designators (Kripke 1980), this is also how they behave in fictional discourse. Others have advanced a rival exceptionalist (E) view. ${ }^{2}$ If 'Pierre Bezukhov' works in War and Peace

${ }^{2}$ Cf. Kroon 1994, Lamarque and Olsen 1994, Bonomi 2008, Motoarca 2014, García-Carpintero 2015, Predelli 2017. Frege also held E, according to Kripke (2011: 58 fn). Thomasson (2010: 127) says that she had "long held" a view in the 
as a disguised description, this is what 'Napoleon' is doing there too. If, as some writers suggest, ${ }^{3}$ declaratives in fictions make truth-evaluable assertions to which prima facie empty names like 'Bezukhov' contribute exotic entities - e.g., the abstract roles that Currie takes them to refer to in transfictive uses-, this is also the way "Napoleon' behaves in War and Peace: it refers to a "surrogate" (Parsons 1980: 57) of the French emperor. Finally, if 'Bezukhov' in War and Peace is not a (real, "genuine") name, 'Napoleon' is not one either there.

Although the topic is also broached in a casual manner by Lewis in a third classical discussion of fictional terms, he considers there an exceptionalist view close to my own: ${ }^{5}$

I do not suppose that ... a distortion of geography need prevent the otherworldly places there called 'London,' 'Paddington Station,' ... from being the same as, or counterparts of, their actual namesakes. But if I am wrong, that still does not challenge my claim that there are worlds where the stories are told as known fact but where it is true that Holmes lives closer to Waterloo than to Paddington. For it is open to us to regard the place-names, as used in the stories, as fictional names

vicinity of E; but in the only previous discussion I have found in her work (1999: 104) she endorses NE, on the basis of the infamous aboutness argument disposed of in $\S 5$ below. As my colleague Enrico Terrone noted, E is "nonexceptionalist" (and NE "exceptionalist") from another perspective - in treating both fictional and real names equally (unequally) in textual discourse. Apologies to the reader for the resulting potential for confusion.

${ }^{3}$ Cf. Ludlow 2006, Manning 2014, Orlando 2017, Predelli 1997, 2002, Stokke (forthcoming); García-Carpintero (2019a) offers more details. I took Voltolini $(2006 \mathrm{a}, 2013)$ to support E along these lines. But he qualifies this in personal communication. He does think that 'Napoleon' refers to a surrogate in what I call below paratextual uses (reporting the content of War and Peace), but he doesn't take this view about textual uses (those constituting the fiction). The way I understand these issues, paratextual uses just ascribe the contents that textual uses put forward for audiences to imagine, so I cannot really see how a wedge can be placed here.

${ }^{4}$ Cf. Currie 1990, Predelli 2017: 146-8.

${ }^{5}$ The treatment of our topic in what by my count is the remaining most influential contemporary discussion, Walton's $(1990 \mathrm{ch}$. 3), is not casual at all; he endorses a form of NE on the basis of arguments not unlike Friend's, discussed below. 
with non-rigid senses like the non-rigid sense 1 have already ascribed to 'Sherlock Holmes' (Lewis 1978: 269) ${ }^{6}$

In contrast with analytic philosophy, $\mathrm{E}$ is very popular in continental philosophy and literary studies. It provides a good interpretation for Riffaterre's (1990: 8) otherwise cryptic remark that "readers need not be familiar with the reality that the text is about in order to believe it true. The only reference against which they need to test the narrative's truth is language”. As $\$ 5$ below makes clear, I reject this formulation of E: readers of War and Peace, given its intended interpretation, need to be familiar with the reality that novel is about (Russia during the Napoleonic wars) in order to fully understand 'Napoleon', and to know what is true according to the fiction. ${ }^{7} \mathrm{How}-$ ever, as I'll show below $(\$ 5)$, there is a core truth in what Riffaterre says: there is always an available interpretation of the work for which what I take him to say is correct.

In this paper I'll go back to this debate. I will address the arguments for NE and against E in Friend's contribution to this volume. I

${ }^{6}$ A referee for this paper defends NE with a reason that raises a serious objection to what Lewis says here: "The reason ... is based on the requirement imposed by a text of narrative fiction on the interpreter. The text will fulfil its narrative functions for her only provided that she imagines (assumes in the as if mode) that the text is a record of utterances of an inhabitant of the actual world (the narrator) who tells us what happened in this world, using e.g. English, as it developed in this world (rather than its fictional counterpart) with its functions known from everyday communication." This challenges Lewis' nonchalant "it is open to us ...": it is not at all clear that it is really open to us to assume that Lewis' fictional narrator is using names in a way that differs from the way their counterparts in the actual world are used. My own proposal (García-Carpintero 2018) is in a better position to address the referee's challenge, but I cannot elaborate on it here. In brief: on my view, truly referential uses of directly referential expressions like indexicals and names trigger descriptive presuppositions. Fictionmakers typically convey their proposals to imagine by "portraying" or "playing" (pretending to be) fictional narrators, thereby pretending to make the relevant descriptive presuppositions. Predelli (2020) develops a concern like the referee's, and a radically alternative account which is nonetheless compatible with both $\mathrm{E}$ and NE (§4.4).

${ }^{7}$ García-Carpintero (2016) argues that E is a central theme of novels such as McEwan's Atonement and Marías Dark Back of Time, and that these writers also take it in Riffaterre's strong understanding. 
will also compare my own views on these matters, and my arguments for them, to Motoarca's (2014). The next section provides necessary background. Although the philosophical ideology in which I cast it is my own, I don't think Friend and I disagree on anything relevant for present purposes. ${ }^{8} \S 3$ advances what I take to be the main argument for E-an elaboration of traditional Fregean considerations. $\S 4$ contrasts intuitions of rigidity about referential expressions in ordinary, assertoric contexts, with intuitions about such terms in fictional uses. $\$ 5$ considers a common argument against E, developing intuitions of aboutness, and turns them around to provide a second argument for NE. $\S 6$ confronts what I take to be the strongest argument for NE, based on considerations of uniformity.

\section{Background on empty fictional terms}

In this section I present necessary background, aiming only at clearly presenting the views, without details and arguments. I refer the reader for them to the works I'll be mentioning, which also contain more thorough references to the proposals that have influenced them.

I'll start by circumscribing our topic. Let us assume that an assertion is what is done by default by means of declarative sentences: "[i]n natural language, the default use of declarative sentences is to make assertions" (Williamson 1996: 258). It is a feature of assertions that we evaluate them as correct or otherwise depending on whether they are true. Let us thus consider three sorts of prima facie assertoric uses made with declaratives in discourses involving fictions:

(1) When Gregor Samsa woke, he found himself transformed into a gigantic vermin.

(2). According to Metamorphosis, when Gregor Samsa woke, he found himself transformed into a gigantic vermin.

(3) Gregor Samsa is a fictional character.

Consider first an utterance of (1) by Kafka, as part of the longer

${ }^{8}$ To a good extent this is because our views are similarly influenced by the work of John Perry. 
utterance by him of the full discourse which, with a measure of idealization, we can think constitutes the act of putting forward his Metamorphosis for us to enjoy. ${ }^{9}$ These uses of fictional declarative discourse, which I will call textual, ${ }^{10}$ are distinguished by the fact that they are not intuitively truth-evaluable. 'Gregor Samsa', we would intuitively say, fails to refer to anything; given this, an assertion of (1) would intuitively fail to be true, and would therefore be incorrect. However, we don't intuitively find it plausible to criticize Kafka on this regard. Textual uses of fictional declarative discourse do not hence intuitively count as assertions.

The other two types differ in that they do intuitively appear to be truth-evaluable, and hence prima facie candidates for assertion. There is, firstly, the use of sentences such as (1) when we report what goes on in a fiction, that is, the character of the fictional world it presents, its plot. I will call these reporting uses paratextual; according to Lewis (1978) and others, they are elliptic for intuitively equivalent content ascriptions like (2), which I'll also count as paratextual. Readers of Metamorphosis would count (1) in such a use as true, as they would (2), and as false the results of substituting 'rat' for 'vermin' in them. Finally, I will call the uses of sentences such as (3) metatextual; they are intuitively truth-evaluable, but not content-reporting, in that they are not obviously equivalent to explicit content ascriptions like (2).

Methodological reasons speak for uniform accounts of fictional terms, aiming to give a similar explanation for their occurrences in our three types of use (Maier 2017: 3). We get two contrasting uniform views, realism and irrealism, depending on whether we take inspiration from, respectively, metatextual or textual uses. Kripke (2013) argues that a proper account of metatextual uses requires interpreting names such as 'Gregor Samsa' in them as referring to exotic entities. Van Inwagen (1977) provides an influential argument for such realism about fictional entities: a Quinean appeal

\footnotetext{
${ }^{9}$ I assume, with Currie (1990), that such acts are speech acts proper, with specific force and contents (fiction-making, as he calls them). This is controversial; some philosophers take them instead to be merely acts of pretending to do something, devoid of the representational aims distinctive of speech acts. Cf. GarcíaCarpintero 2019b, 2019c, 2019d.
}

${ }^{10} \mathrm{I}$ borrow this and the other two related labels from Bonomi 2008. 
to non-eliminable quantification over, and reference to, such entities in prima facie serious, truth-evaluable discourse, such as utterances of (3) and related metatextual uses in contexts of literary criticism. ${ }^{11}$ Such ficta could then be taken to be (as both Kripke and van Inwagen recommend) abstract existent entities of various sorts, fully-fledged Platonic abstracta, ${ }^{12}$ or rather created artefacts. ${ }^{13}$ These fictional entities could then be invoked to account for textual and paratextual uses. ${ }^{14}$

Focusing on metatextual uses thus leads us to think of (1)-(3) as uniformly including referring names, and uniformly making assertions. Focusing on textual uses leads instead to a uniformly irrealist picture. When the creator of a work of fiction uses sentences such as (1), we do not intuitively think of her as really performing the speech acts that one typically performs with them in default contexts. The sentences are used in some form of pretense, like the acts that actors perform on stage: they do not need to be actually drinking whisky, they merely pretend to do so. Hence, we do not evaluate them by invoking any norms we would apply to serious uses.

Now, if the apparent assertions are merely pretend, the same might apply to the apparent (ancillary) acts of reference; and in this way an avenue is opened to account for such uses without the need to posit actual referents for fictional singular terms. ${ }^{15}$ This is, I take it, Friend's

${ }^{11}$ The editors' "Introduction” to Brock and Everett 2015 provides an excellent summary of this and other arguments for and against realism about fictional characters, and further references.

${ }^{12}$ Cf. Wolterstorff 1980, Currie 1990.

${ }^{13}$ Cf. Salmon 1998, Thomasson 1999, 2003 and Schiffer 2003. Kroon and Voltolini (2016) provide helpful discussion of these alternatives.

${ }^{14}$ Cf. Predelli 1997, Reimer 2005, Ludlow 2006, Voltolini 2006b, 2016, Manning 2014, Orlando 2017, Stokke (forthcoming). The extension is not straightforward; it might require to discern an ambiguity in predication, or extra levels of context-dependence as in Predelli 2002: while exotica of any of the sorts we have contemplated can be taken to truly exemplify in actuality predicates like 'is a fictional character', prima facie they are not in the extension of the likes of 'is a vermin'. See Everett 2013: 170-7 for critical discussion.

${ }^{15}$ Walton (1990) provides a sophisticated and deservedly influential account of textual uses along such lines, which he then extends to deal with both paratex- 
(2007) preferred picture, and it is also mine. But as before with the realist picture, the extension from the best case for the irrealist approach - textual uses - is not straightforward, here because there does not appear to be any pretense in assertions of (2)-(3). The intuitively best option would be to combine fictional realism for metatextual uses, as in (3), with a pretense-theoretic account of textual uses of sentences like (1); this is Kripke's (2013) “pluralist” suggestion, on which fictional names such as 'Gregor Samsa' have an empty, pretend use in (1), but a related non-empty serious one in (3).

In addition to the resulting profligacy, however, paratextual uses occupy a problematic middle ground for this ecumenical rapprochement. As Everett (2013: 163-78) emphasizes, there are mixed cases such as (4); here whatever 'Gregor Samsa' designates is ascribed both properties of a human being, and those of an abstract character:

(4) At the start of Metamorphosis, Gregor Samsa - an emotional alter ego of himself created by Kafka for his best known novel - finds himself transformed into a gigantic vermin.

Everett takes this as a reason to extend the irrealist pretense-theoretic account to paratextual and metatextual uses, but the case can be made in the opposite direction. ${ }^{16}$

Issues about fictional terms have been one of the traditional motivations for descriptivism about names. Lewis (1978: 267) and Currie (1990: 159) defend a standard version for names in textual and paratextual uses, which deals with them by means of a Fregean account of attitude ascriptions. In my work on reference, ${ }^{17} \mathrm{I}$ have articulated and defended a metalinguistic descriptivist presuppositional view that, I argued, accounts for the "singularity" data that Friend (2011, 2014) marshals against traditional descriptivism like Lewis' and Currie's. ${ }^{18}$

My allegiance to such a descriptivist account notwithstanding,

tual and metatextual uses; Everett (2013) offers an illuminating, precise elaboration of the program.

${ }^{16}$ Cf. Recanati 2018 for a good discussion of these matters.

${ }^{17}$ Cf. García-Carpintero 1998, 2000, 2006b, 2017.

${ }^{18}$ Cf. García-Carpintero 2010a, 2018; García-Carpintero (2019a) outlines it. Alward (2011) and Maier (2017) provide similar accounts. 
I do not have qualms with the referentialist, exotic-object treatment of (1)-(3). ${ }^{19}$ We commonly resort to the apparatus of reference (names, identity, existential quantification over the positions names occupy, anaphora on those positions) for hypostatizing purposes. This is a convenient recourse that I'll use. It should be taken as a form of pretense. ${ }^{20}$ This alternative assumption will combine (in pretense, unlike what they suggest) the proposals in Walters (ms) for metatextual discourse, and Predelli (1997, 2002), Orlando (2017) and Stokke (forthcoming) for textual and paratextual uses.

On this way of presenting the view, the pretend-referents are created abstract artefacts. ${ }^{21}$ Predication is understood as in uniform realist proposals, as ambiguous between exemplification in metatextual discourse, and encoding in textual and paratextual discourse. Apparent assertions are pretend-conventional, semantically indicated, "shallow" (Kroon 2004, 2005) pretense. This provides a straightforward account for mixed cases like (4). As Recanati (2018) and Walters (ms) show, on this view it reproduces a common pattern that (5) illustrates, when a sculptor utters it about one of her creations, seamlessly combining the two different forms of predication:

(5) That lion is the best sculpture I've made this month; it is as ferocious as the one we saw yesterday at the zoo.

${ }^{19}$ Cf. García-Carpintero 2019a, 2020. Motoarca (2014) also assumes such an account.

${ }^{20}$ García-Carpintero (2010b) defends it for metatextual discourse, as a form of Yablo's (2001) figuralism; cf. also Yablo 2014a, Hoek 2018. On my metaphilosophical views, close to Yablo's (2014b) quizzicalism, the differences between the descriptivist and pretend-realist views might well be merely verbal, in the sense of Chalmers (2011b).

${ }^{21}$ Something along the lines of the ideas for fictional characters of Everett and Schroeder (2015), Walters' (ms) representations thereof in fictions, or Recanati's (2018) metafictional files. While this "surrogate" view that I'll thus assume posits as fictional characters created abstract artefacts, like Salmon (1998) or Thomasson (1999), Motoarca (2018) defends the traditional view of Wolterstorff (1980) and others that they are Platonic atemporal entities. Given my ultimate irrealism on these metaphilosophical issues, I don't really care much how we think of ficta. But I must say I am unmoved by Motoarca's arguments, which rely on intuitions about sameness of fictional characters across works that I don't think might carry much weight. 
Negative existentials cannot be treated on this variant as straightforwardly as in the negative free logic proposal by Walters (ms); but no treatment of negative existentials, whether that, or the even less committal substitutional account by Sainsbury (2018 ch. 2) will be straightforward.

\section{The master argument for NE}

I move now to present my reasons in favour of $\mathrm{E}$ and my take on criticisms of it. I'll start in this section with what I take to be the main consideration in favour of $\mathrm{E}$. Consider these examples, parallel to our initial ones, this time uttered with regard to Tolstoy's War and Peace:

(6) Bezukhov fought in Borodino but didn't chance on Napoleon there.

(7) According to War and Peace, Bezukhov fought in Borodino but didn't chance on Napoleon there.

Our question concerns the way 'Napoleon' and 'Borodino' work in a textual use of (6). When it comes to the content of a straightforward default assertoric use of (6), according to my direct reference view names just contribute their referents: the emperor and the battle. That use would put forward a "gappy" singular proposition, untrue at the actual world, given that 'Bezukhov' is empty or signifies a fictional character. It doesn't refer to Tolstoy, say, even though he apparently modelled the character on him. This is underwritten by a principle that Mole (2009: 478-81) articulates, to the effect that norms fixing fictional contents do not allow importing facts about Tolstoy to portray Bezukhov: "Fictional items do not inherit the properties of the real-world items from which they were drawn unless these properties are introduced ... in canonical sentences. Real items do" (2009: 479). We are not entitled to invoke facts about Tolstoy to characterize Bezukhov, unless the fiction explicitly says it so, even if Beuzkhov was drawn on Tolstoy. This sets 'Bezukhov' apart from 'Napoleon' in War and Peace.

This, however, leaves open what the contribution of names to the content conveyed in a textual use is. In previous work GarcíaCarpintero (2010a: 286-7, 2018 §4) I have argued against the view 
that textual uses don't express propositions, on account of their being "mere pretense": ${ }^{22}$ on the contrary, I argued, they put forward a specific content for audiences to imagine. A parallel sometimes drawn between textual and paratextual uses on the one hand, and sentences embedded under intensional operators on the other then offers an initial case for E. Lewis (1978: 262), Kripke (2013: 74) and others assume that paratextual uses are elliptical for the likes of (2) and (7). Devitt (1981: 172) defend a similar account for textual uses, on which they are elliptical for sentences with an operator read as "it is pretended that" (cf. also Orlando 2017). Assuming currently standard views in semantics on the interpretation of intensional operators, on these views the motivation for E becomes a familiar Fregean semantic affair.

There are, however, serious objections to ellipsis views (Bertolet 1984). Predelli (1997), Recanati (2000, 213-26), Reimer (2005) and Voltolini (2006b, 2016) advance alternative but equally semantic contextualist views. The context in which 'The battle happened here.' is uttered might require us to evaluate the assertion not with respect to the place where the utterance occurs, but rather with respect to another, contextually provided location. On Predelli's, Reimer's and Voltolini's views, the context of textual and paratextual uses of (1) and (6) similarly leads us to evaluate their truth not at the actual world, but at a counterfactual or imaginary one, "the" world of the fiction (or a plurality thereof, on Lewis' (1978) view those in which the story is told "as known fact"). ${ }^{23}$ Predelli (2002) discusses cases involving fictional names, arguing that they refer to

${ }^{22}$ Cp. Kripke 2013, Walton 1990, Reimer 2005, Predelli 2017, 2020, and Recanati 2018. Predelli's (2020) Radical Fictionalism, the best development I am familiar with of this view, addresses my previous concerns, and merits a deeper appraisal.

${ }^{23}$ Once more, this is not my own view. I don't think it is a good idea to count textual uses as assertions, to be evaluated as literally true or otherwise, except that not at the actual world but at "the" world of the fiction. On my view they are not assertions, but alternative acts to be evaluated with respect to norms other than truth vis-à-vis the character of "the" fictional world they represent (cp. Walton 1990: 41-2). However, as Everett's (2013-48) suggests, perhaps the difference here is not big. In any event, this doesn't affect the current issue. 
exotic objects - actual abstract created existents. ${ }^{24}$ I'll assume this view for paratextual and textual uses; as with realism about fictional characters, this is just a convenient pretense.

With this background, the master argument for E appeals to, and motivates, a systematically Fregean treatment of terms in the discourses we are considering. If 'Bezukhov' refers to an abstract representation (or is a disguised metalinguistic description, in my real view that I am putting aside for convenience), prima facie we should say the same about 'Borodino' and 'Napoleon' in the relevant discourses. This should be justified, however. While Frege assumed that terms in intensional contexts always change their reference, de re ascriptions show that this cannot be correct. The formal accounts of attitude ascriptions that could be used to formalize the semantic proposal I am making acknowledge this, by allowing terms to keep their ordinary referents in attitude ascriptions. ${ }^{25}$ But I claim that terms with real referents always stand in textual uses for abstract representations, surrogates of their usual referents - or always behave like disguised descriptions, in my real descriptivist view. ${ }^{26}$ This requires further argument.

The main argument for E highlights what Lamarque calls the "opacity" of fictional representations. ${ }^{27}$ Here is a Fregean argument to elaborate on this. ${ }^{28}$ Let's imagine a fiction, The Ferrante Affair, in

${ }^{24}$ As far as I can see, he makes no commitment one way or another about $\mathrm{E}$ in these works. Cf. Orlando 2017 and Stokke (forthcoming) for related recent views.

${ }^{25}$ Cf. Maier 2010, 2016, 2017, Chalmers 2011a, Pickel 2015.

${ }^{26}$ There might of course be paratextual de re ascriptions. Friend's example of Alena using 'Leningrad' to report about "The Nose" (this volume, §6) is one. Standard Fregean treatments of such cases take the "mode of presentation" that properly characterizes the corresponding part of the fictional content (to wit, city called Saint Petersburg) to have been in those reports existentially generalized away. Cf. Kaplan 1969, and the references related to Kaplan's (1989: 555) "pseudo de re" below, fn. 33 .

${ }^{27}$ Cf. Lamarque and Olsen 1994: 126; Lamarque 2014 ch. 8.

${ }^{28}$ Cf. Kroon 1994, Motoarca 2014: 1044-6. In García-Carpintero 2018 §5, I use a variation of the argument against Friend's (2014) account of co-identification involving fictional terms. In my example there, a fiction-maker builds two manifestly different characters on (different traits of) herself. Good real cases 
which the author (perhaps a playful postmodernist, or just someone ignorant of the facts I'll presume) has two manifestly different characters, called 'Domenico Starnone' and 'Elena Ferrante'. The latter has in the fiction the features that a reader of Ferrante's writings would ascribe "her", based on what is publicly known. The former has the traits that the Italian writer is publicly known to have. Imagine further that, as some research suggests, Ferrante is in fact Starnone. ${ }^{29}$ Under these conditions, NE entails that textual uses of (8) and (10) make the same proposal to imagine as (9) and (11); that paratextual uses assert the same propositions; and that, when prefixed with 'according to The Ferrante Affair', they have the same truth-value:

(8) Starnone wrote Denti.

(9) Ferrante wrote Denti.

(10) Starnone is not Ferrante.

(11) Starnone is not Starnone.

These consequences are, I take it, clearly wrong. How could the defender of NE block them? In presentations of this material, David Davies suggested that, given the circumstances of the case, 'Starnone' (and 'Ferrante') should be treated as fictional terms; i.e., that they should be treated in accordance with E, without endorsing the view in general. ${ }^{30}$ But this seems ad hoc (Motoarca 2014: 1046). I men-

that I can think of to make the Fregean argument below are similar. In fictions working out the theme of the double like Villeneuve's 2013 film Enemy and Polanski's 2017 D'après une histoire vrai (as in the Saramago and de Vigan novels on which they are based), the double characters (Adam and Anthony in the former, Delphine and Elle in the latter) in fact inhabit a fiction-within-the-fiction (respectively, a Kafkian nightmarish phantasy, and a novel that is being imagined-the very one we are reading), in which they are different surrogates of a single character in the fictional world.

${ }^{29}$ https://www.researchgate.net/publication/320131096_Elena_Ferrante_ Unmasked, downloaded on 26/7/2018.

${ }^{30}$ Friend's response to the case (this volume, §6) appears instead to bite the bullet that textual uses of (8)-(9), (10)-(11) present the same contents to be imagined. While I accept that someone asserting (10) is thereby (rationally, un- 
tioned above Mole (2009: 478-81) normative criterion for the distinction between "real-world items" (indicated by non-empty names) and "fictional items" (indicated by empty ones): the former, but not the latter, allow for the importation to the fiction of properties that the referent has in actuality. I am assuming that this applies in our case: we are invited to round off the two characters with information from the actual world not explicitly stated in them, consistently with the novel's distinction between Ferrante and Starnone.

Importation principles have consistency restrictions, like the one just mentioned. Thus, Mole (2009) limits the relevant norm, allowing to import properties of referents "except when these properties are explicitly suspended for the purposes of the fiction". It might be thought that this would allow to answer the challenge of ad hocery, but this would be confused. The Ferrante Affair invites imagining what (8) and (10) here convey, either explicitly, or implicitly; then NE (given direct reference) entails that it thereby invites imagining the content of (9) and (11), which is the same under the assumptions. Nothing can "suspend" this. What the restriction might suspend is, say, that the writer named 'Ferrante' there wrote Denti, or that the writer named 'Ferrante' is the writer named 'Starnone'; but this just adds to the tension.

Before rounding up the argument in this section, a point on Friend's practice of representing the structured singular propositions she identifies as textual contents by subscripting the references to real objects with terms for ways of thinking ('mop') of them (Friend 2011: 197-9). She admits this much (this volume, §5): “[t] he notion is not part of the referential content, but instead specifies the way in which we are supposed to imagine that content. Fulfilling an invitation to imagine requires imagining the right content in the right way, by deploying appropriate notions. The same is true for invitations generated by nonfiction". As I'd put it, in order to fully understand the assertion of a singular content, I must grasp

like what would be the case if she asserted (11)) asserting an impossibility, it doesn't follow that someone using it to ascribe a belief is thereby ascribing belief in something impossible. By the same token, as I am arguing, it doesn't follow that the fiction-maker I am imagining is putting forward (10) to invite us to imagine a fiction with an impossible content. I'll say something below, fn. 40, about Friend's suggestion in that passage that the specific case of the "playful postmodernist" author actually supports NE. 
descriptive reference-fixing presuppositions (Perry's reflexive propositions, Stalnaker's diagonal propositions). But what I have to believe in order to accept the assertion is not individuated in any way by these descriptive affairs. That is what direct reference comes to; this is how anybody who disbelieves the same singular content disagrees with me, and can properly challenge me, even when she is identifying the relevant objects by making entirely different presuppositions. I thus understand that Friend accepts that, in prescribing us to imagine (the contents of) (8) and (10), The Ferrante Affair is eo ipso prescribing us to imagine (9) and (11). By placing a subscript for the 'Ferrante' mop to 'Ferrante', and a different one for the 'Starnone' mop to 'Starnone' in the representation of the relevant contents, Friend would not be intimating that the fiction prescribes imagining the former without prescribing imagining the latter, for this would be giving up NE.

Ad hoc maneuver or not, as we have seen some supporters of NE are open to treat some occurrences of real names in fictions in accordance with E. We thus still need a justification for the general claim that E makes, beyond the appeal to particular cases like the one that The Ferrante Affair illustrates. Such justification comes from Lamarque's (2015 ch. 8) "opacity” considerations. He develops them by discussing examples from actual literary cases, aiming to generalize the point made with such examples. I have elaborated before on the general point behind the Fregean intuitions in ways I'll expand on now.

Why is it that names contribute just their referents to their default use - their contribution to the content of assertions made with simple sentences - but they contribute something else to (some) attitude ascriptions? When we make an ordinary assertion with a simple sentence including a demonstrative or a name, the content is singular, gappy if the associated referential act is unsuccessful; the reference-fixing description is merely presupposed. This reflects the fact that, although grasping the description is essential in context for fully understanding the assertoric act (which is what Friend's subscripting practice aims to capture), someone can grasp the very same content - thereby coming to be in a position to evaluate our act with respect to its constitutive normative features: truth, informationprovision-aptness - without representing the relevant object in the same way. This is precisely what is not the case when it comes to the 
contribution of names and indexicals embedded in attitude ascriptions to the content of such sentences in some contexts. Now, the same applies to their contribution to the content that audiences are prescribed to imagine in textual uses; The Ferrante Affair merely illustrates this. I'll go back to these more general considerations for $\mathrm{E}$ in the final section, $\S 6$.

\section{Names in fiction and intuitions of rigidity}

Given direct reference, NE entails that real names in textual uses are rigid, a conclusion that Kot'átko (2010) stresses. Do we have standard intuitions of rigidity about such uses? It is not an easy matter to probe them, but it is worth trying. Soames (2002: 251) offers a convenient Kripke-based test. Ordinary speakers (or at least those among them able to process long and complex sentences including modal operators) find (12) clearly true, and (13) clearly false:

(12)The person who was in fact Napoleon might not have existed without being Napoleon (and no one other than that individual might have been Napoleon).

(13) The person who was in fact the victor in Marengo might not have existed without being the victor in Marengo (and no one other than that person might have been the victor in Marengo).

Now, I find (14) as false as (13); for entirely analogous reasons, I also find (15) false:

(14) The person who was in fact Bezukhov in War and Peace might not have existed without being Bezukhov in War and Peace (and no one other than that person might have been Bezukhov in War and Peace).

(15)The person who was in fact Napoleon in War and Peace might not have existed without being Napoleon in War and Peace (and no one other than that person might have been Napoleon in War and Peace).

(14) and (15) fail for obvious reasons: the work might not have been produced, without that depriving Tolstoy (the person who was Be- 
zukhov in War and Peace according to some critics) or Napoleon of existence. The parenthesized part in (14) also fails, because Tolstoy might have based the Bezukhov character on someone else, or a combination of different people, without that affecting the character of the novel. The parenthesized sentence in (15) fails for analogous reasons. We can imagine a literary historian defending the view that in fact Tolstoy was a poor researcher, very incurious and poorly informed about history, who knew nothing of the French emperor and his exploits, and wrote instead about, and on the basis of input from, a mad military countryman he met who called himself Napoleon and told him a bizarre "autobiography" he had concocted.

In line with related points Friend makes, deploying the Uniformity considerations that I will confront in $\S 6$, one might point out in response that the failures of rigidity that (15) exhibits are created by the phrase 'in War and Peace', which generates intensional contexts. The same failures would occur if we apply a similar test relative to a nonfictional work such as Andrew Roberts' biography (substituting 'in Roberts' Napoleon the Great' for 'in War and Peace' in (15)), in spite of the fact that, as I agree, declaratives there convey singular contents. ${ }^{31}$

This is right. I take phrases like $A$ as $F$ is $G$ ('John as a judge makes only 50.000\$ a year', 'Napoleon (as represented) in Roberts' biography is admirable') roughly to mean $A$ is $F, A$ is $G$, and the latter obtains as part/on the grounds/on account of the former (Szabó 2003, Asher 2006)). Although $A$ occurs in a referential position, the implicit

\footnotetext{
${ }^{31}$ This is not Friend's response, however. She claims that "given that Tolstoy referred to Napoleon in War and Peace, no one else could be Napoleon in War and Peace" (this volume, §6). I assume the modality here is metaphysical; two-dimensionalists like Stalnaker (1978) standardly take it that the Napoleon of Roberts' Napoleon the Great could have been someone else (granting that Roberts referred to Napoleon in his work) in the epistemic sense of the modality the view needs for its articulation. The suggestion that Napoleon himself, with all his organs, is constitutive of the essence of the character that Tolstoy created, given that he was writing about the French emperor, is intriguing. I don't find it prima facie compelling, though: would an alternative creation history for War and Peace like the one just imagined make it a different fiction? To be sure, it wouldn't allow for importation of facts about the French emperor, and hence its content would differ from the actual one, cf. $\S 5$. But we can make sense of the idea that fictions might have had different contents than they actually have, which philosophers like Thomasson (1999) and, indeed, Friend (2011) exploit for their argumentative purposes.
} 
'represented' plus the grounding element creates opacity, not unlike that in 'Giorgione was so called because of his size'. Compare 'Starnone in The Ferrante Affair wrote Denti': we cannot substitute salva veritate 'Ferrante' for 'Starnone' there, in spite of occupying a transparent position, and whether or not we take The Ferrante Affair as a fiction. This is thus again the familiar Fregean point that names may convey richer content than their referents in intensional contexts, hence in paratextual uses.

In asking the reader to consider (15), I wasn't overlooking this. I was trying to prod non-rigidity intuitions motivating E for textual uses, which I take to be in sync with the Fregean intuitions triggered in the previous section. While reading Roberts' biography, I can consider (12) as a claim about this character referred to there with 'Napoleon', perhaps too admiringly portrayed. I still find it as unhesitatingly correct as usually; i.e., I fully share Kripke's rigidity intuitions when it comes to the worlds for which the biography is correct: they share the facts involving Napoleon, the same guy in all of them, the one picked out in actuality by the specific name 'Napoleon' being considered. I was aiming to nudge the reader into questioning them, in contrast, when taken about the character that goes by that name in War and Peace, i.e., when it comes to considering the worlds of the fiction, those it prescribes us to imagine. To me at least, it doesn't matter who plays the Napoleon role there; it only matters that the role (to be sure, incorporating features imported from commonly known facts about the emperor) is played in the way the fiction mandates. It could be the madman of the fantasy above, for all I care. ${ }^{32}$

In sum, I doubt that theoretically unbiased speakers have clear intuitions of rigidity in the fictional case. In the next section I'll probe further these intuitive considerations of aboutness; I'll critically engage there a popular argument against NE, based on such considerations.

\footnotetext{
${ }^{32}$ This is just to say that on my own intuitions 'Napoleon' in War and Peace works in the descriptive way Lewis' envisages for 'Waterloo' and 'Paddington' in the quotation above, $\S 1$, or in the role-designating way that Stokke (forthcoming) defends for fictional names. Friend obviously doesn't share my intuitions, given her response just mentioned.
} 


\section{Aboutness considerations, for and against E}

I will not examine at length here the argument against NE based on intuitive considerations of aboutness, because I take it that exceptionalists have decisively shown that it should carry no conviction (Lamarque and Olsen 1994: 108; Motoarca 2014: 1035; GarcíaCarpintero 2015: 158-63). I will go back again to it mostly because, like Motoarca (2014: 1042-4), I think that the tables (i.e., considerations of aboutness) can be nicely turned on supporters of NE. I also have to, because Friend still takes them to highlight the "central flaw" in E (this volume, §6).

Frege's "shifting reference" view of the semantics of terms in attitude ascriptions invites the thought that terms there "are about" their senses. If we think of their contribution along the pretend-exotic-realist alternative that I am allowing, this is even more clearly encouraged. We would then say that, given E, textual and paratextual uses are about descriptive senses, or the corresponding abstract representations, roles. The flexibility of the ordinary notion of aboutness - parallel to that of something - supports this. But this very same flexibility disallows the inference that the relevant acts hence are not about the entities that such things, descriptions or abstract surrogates, represent. On the contrary, there is thereby "something" else they are about, even in the empty cases and even assuming my irrealism about them (see Sainsbury 2018 ch. 2). Russell (1903: 316) puts the point succinctly for the non-empty case, discussing sentences of the form 'The Prime Minister of England is F.': "[A]lthough ... Arthur Balfour forms no part of the meaning of this proposition, yet there is a sense in which this proposition is about Mr. Arthur Balfour. For the proposition is certainly about the present Prime Minister of England; and the present Prime Minister of England is Mr. Arthur Balfour". ${ }^{33}$ In slogan form: aboutness is intuitive and malleable; singular

\footnotetext{
${ }^{33}$ Aboutness in the sort of case Russell is discussing corresponds to Boër and Lycan's (1986: 125-32) lowest "grade of de re involvement", which in previous work I invoked to make the same point (García-Carpintero 2015: 159). Cf. classic discussions of Kaplan's (1989: $555 \mathrm{fn}$ ) pseudo-de re — essentially, the disparity between intuitively cheap de re ascriptions and theoretically costly singular contents_-, in particular Salmon (2004) and Burge (2009).
} 
reference is theoretical and constrained. ${ }^{34}$

Friend nonetheless considers "the central flaw in the descriptivist approach" to be "the conflation of modes of presentation [...] and the subject matter of our imagining about that individual" (this volume, §6). She claims that, on the sort of account I am advancing, "the distinction between imagining about real individuals and imagining about fictional characters collapses ... However, it just looks false that reference makes no cognitive difference" (ibid.). But I fully agree that it does, and I firmly reject that the distinction collapses on my account. There is a very significant cognitive difference between pretend-presupposing that there is something picked out by a naming-practice constituted in the very fictional text that invites imagining it - like the 'Gregor Samsa' practice — and doing it with respect to an independently existing one, like the one for 'Napoleon' in War and Peace. Unlike the former, the latter picks out a real individual in the actual world. By the same token, the corresponding surrogatethe abstract representation of Napoleon in War and Peace - acts as proxy for that individual.

This, I submit, is enough to explain why we can apply in the latter case Mole's norm (2009: 478-81), allowing to import facts about the real man compatible with it. It also explains why readers are entitled to the mirror exportation inference, through the mechanism that Gendler (2000: 76) calls "narrative as clearinghouse: I export things from the story that you the story-teller have intentionally and consciously imported, adding them to my stock in the way that I add knowledge gained by testimony". I may thus export singular propositions about Napoleon and Borodino from War and Peace for me to believe, the way that Gendler outlines.

Friend (this volume, §3) objects: "It is at best ad hoc to maintain that I believe a singular proposition as a result of imagining an entirely different proposition". But there is nothing ad hoc in the mechanism just described, given the sort of account I am relying on, mentioned in $\S 3$. I do assume that (in the order of semantic explanation, without

${ }^{34}$ As Grzankowski (2018: 143) puts it, “the object of an attitude needn't be what the attitude is 'directed towards' or 'about' and in typical cases it isn't ... It is typically misguided to say that propositional attitudes are about or directed towards propositions"; the same can be said of the propositional constituents. He goes on to nicely elaborate on the point my slogan sums up. 
any cognitive or epistemic implications) we first export from War and Peace the descriptive propositions that Stalnaker (1978) calls "diagonal propositions" and Perry (2012) "reflexive propositions”. But both Perry and Stalnaker would agree that we understand both these and the corresponding singular propositions in all ordinary cases. Perhaps they would even agree with me that understanding the descriptive proposition grounds understanding the singular proposition, when this is not meant (as I am not meaning it) as a claim about what goes on in actual online processing.

Friend's charge assumes that singular propositions and descriptive propositions are "entirely different". On the sophisticated descriptivist view I have developed, they are not far apart. There are strong theoretical reasons that the propositional constituent contributed by a name in textual contents is a description, or the corresponding surrogate - the Fregean and rigidity considerations in the previous sections, and the indeterminacy ones below. This theoretical claim is not impugned by the intuitive feeling that the fiction "is about" what the description describes, or the surrogate is proxy for. The theory provides the needed relation between the theoretical propositional posit, and the object that our intuitions take the fiction to be about.

The duality of aboutness allowed by $\mathrm{E}$ (the propositional constituent on one side, the object it picks out on another) turns out to be explanatorily helpful in mixed cases, which gives $\mathrm{E}$ abductive advantage over NE. We can think of soritical series of fictions using names articulated as 'Napoleon', starting with those like War and Peace straightforwardly allowing for importation and exportation of facts about the French emperor, ending with others clearly precluding them. Motoarca (2014: 1038-42) considers such a series, and uses it in a metasemantic argument for NE. I find it unpersuasive because it overlooks that metasemantic indeterminacy afflicts $E$ as much as it does NE. I will first critically discuss it, to be in a better position to appreciate the true explanatory advantages afforded by the aboutness duality that E allows.

At one side of the metasemantic soritical series that Motoarca discusses we have fictions like War and Peace, which are clearly about Napoleon, the French emperor. At the other, he considers fictions using a name orthographically articulated in the same way, whose authors don't intend to use it in any way following the actual practice 
on which it refers to the French emperor. It may be used to designate in the relevant fiction a pet, or a logarithm. In such cases we are clearly banned from importing and exporting facts about the general defeated at Waterloo. Motoarca doesn't offer illustrations of the intermediate cases he correctly thinks there might be. Stephen Vincent Benét's 1937 short story The Curfew Tolls provides I think a real example, for it is unclear whether the Napoleon character there "is" the French emperor: ${ }^{35}$ the story admits an interpretation allowing to import facts about him to delineate its world, but also another that doesn't, on which the character is merely fictional.

Motoarca builds an alleged reductio of the NE assumption that 'Napoleon' in the initial stories in the sorites stands for the real man. He argues for it against three exhaustive options derived from NE: (i) the name keeps this meaning across the whole series; (ii) there is a borderline area; (iii) there is a sharp, unknowable cut-off point. He concludes that we must discard the assumption. But the argument is unpersuasive, because the very same considerations would dispose of E, thus entailing a contradiction.

To see this, note that in purely fictional cases we have different stories that are about the same character, like the different Holmes'

\footnotetext{
${ }^{35}$ In this epistolary story, the narrator tells his sister in letters spanning from September 1788 to May 1789 about a character (whose name is revealed at the end to be 'Napoleon Buonaparte') that he has met at a thermal resort in France. The character is a retired artillery major, believed to be Sardinian but later revealed to be Corsican, born in August 15, 1.737, eventually dying in May 5, 1.789. He has a huge self-regard, a wife called Josephine and an older brother called Joseph whom "he had had the ambition of making king"; a serious knowledge of military history and well-thought views about how famous battles should have been fought. He regrets not having been born in 1769, because in that case he thinks he might have had the opportunities he has sadly missed to deploy his actual military genius. There is no doubt that we must keep the French emperor in mind to properly appreciate the story; for its theme is the extent to which one's life achievements depend on (moral) luck. But I find it acceptable to interpret it so that the characters are nevertheless not (proxy for) Napoleon and his family, living lives moved back in time 32 years, but merely fictional characters with coincidental lives, while the actual Napoleon born in 1769 is still part of the fictional world. Friend (2017) also argues for interpretive pluralism, although perhaps she would find the one I advocate for too profligate.
} 
installments. ${ }^{36}$ This is readily explained. If we take names to be the disguised descriptions that my official account roughly suggests, the name stands in the stories for the same metalinguistic description, deploying the same specific name, plus whatever additional identifying information is added to this. If we take instead the realist alternative, the name refers in the different stories to the same abstract created representation. There are similar cases involving fictions using real names. There might be a Tolstoy sequel to War and Peace, in which Napoleon also shows up; in fact, King Vidor's (1956) film version of War and Peace suffices to make the point. E allows the same alternatives for the contribution of 'Napoleon' as in empty cases: it stands for the same description, or it refers to the same abstract object. Now we can generate a similar metasemantic sorites with respect to cases of this sort, but this time assuming E instead of NE. If Motoarca's reductio was valid, an analogous one would now dispose of E. However, Motoarca correctly takes E and NE to be exhaustive alternatives.

We thus need to look for a different culprit than NE in the premises on whose bases Motoarca rejects the three options (i)-(iii). (i) is unassailable, but Motoarca's considerations against (ii) and (iii) overlook metasemantic indeterminacy. As Perry (2009) shows, there are similar cases involving the metasemantics of demonstrative reference - "picture of Carnap/Agnew" Kaplan-like cases for which whatever sensible metasemantic considerations we can ascertain leave what the semantic referent is indeterminate. There will thus be cases in which it is left indeterminate by the correct metasemantics whether 'this is a picture of a great philosopher' is true or false. Motoarca (2014: 1041) is right that, if (ii) fails, there will be cases in which it will be similarly indeterminate whether the ascription of a property to Napoleon is true or false (in the relevant story). But I fail to see why this is more problematic than indeterminacies in asserting baldness of the real man. Although I don't like the epistemicist option (iii) (cf. García-Carpintero 2020), Motoarca's argument

${ }^{36}$ Motoarca might reject this assumption, but that would be costly. We should then weigh on the one hand the perfectly compelling theoretical accounts of the ordinary intuitions supporting it (Walters 2017); and, on the other, Motoarca's motivations for rejecting what I take to be the most plausible option for avoiding his reductio, (ii). To me, the balance should be clear. 
against it is similarly problematic. He is right that this alternative explanation assumes an apparently arbitrary cut-off point; but there is no relevant difference with the baldness and demonstrative case. If epistemicism is right for them in spite of my prejudice, it equally explains the metasemantic indeterminacy we have been considering. ${ }^{37}$

We can now go back to our main thread. We have seen that, quite independently of $\mathrm{E}$ and NE, there will be soritical metasemantic series, starting with fictions clearly allowing importation and exportation with regard to a real object like Napoleon, ending with others clearly banning them, with indeterminate cases in between. I mentioned the Vincent Benét example to illustrate the latter possibility. Cases like 'Bezukhov' in War and Peace, or, in general, cases of roman-à-clef novels lie closer to the "banning importation" end of the spectrum, but they are also interesting for my goal of turning the tables of the aboutness considerations on NE. ${ }^{38}$

${ }^{37}$ Gómez-Torrente (2019) explores in great depth the topic of metasemantic indeterminacy. I also rejected in my previous contribution (García-Carpintero 2015: 164-6) Bonomi's sophisticated version of another indeterminacy argument for E. This is the argument that Napoleon in War and Peace cannot be the real Napoleon, because, unlike the latter, it is an "indeterminate" entity, many of his features being left open by the fiction. To base E on this is a glaring nonsequitur. Only weird postmodern fictions explicitly about indeterminate entities have them as characters, and their very weirdness makes them irrelevant to make a good case for E. Indeterminacies about Napoleon in War and Peace can be dealt with by, say, acknowledging that there is not "the" world of the fiction, but a plurality thereof (cf. García-Carpintero 2020).

${ }^{38}$ Rebecca Goldstein's The Mind-Body Problem and Anne Fine's funny and compassionate Taking the Devil's Advice are well-known examples among philosophers. Luisa Castro's poignant La Segunda Mujer (2006) is equally notorious in Catalonia. (The author denies that the novel is a roman-à-clef, claiming that it is purely fiction; but plausible deniability is of course essential to the genre.) For those in the knowing, it fictionalizes the story of the novelist's eventually failed marriage to a locally egregious character - a local philosopher, member of that heute bourgeoisie that has recently become politically radicalized pursuing secessionism, in fact an ideologue for such views. Gossiping dispositions partly motivating these reads were rewarded here. One could learn (i.e., export) unsurprising facts about the role in the marriage dissolution of the anti-Spanish despite that plays such an important role in the secessionist movement; but one could also learn juicy facts, less familiar at the time, concerning the huge level of corruption in the closest family circles to the nationalist president of the Catalan government for many 
I will resort to a variation on Walton's (1990) distinction between official and unofficial pretense to account for these cases. Usually, the fictions are officially addressed to an audience that is not supposed to be familiar with the similarities between them and the real world that justify taking them to be about real characters. The relevant terms are thus officially understood to be merely fictional: readers are not supposed to import information about real characters to their pretense - to their construction of the official fictional world; exportation is also officially unsupported. However, fiction-makers count on the required matches being available to part of their audience. This gives rise to a different, unofficial interpretation, which does allow for importation and exportation. ${ }^{39}$ There might be cases in which the real-object involving interpretation can be considered as official as the purely-fictional-object one, thereby creating occasions for further indeterminacy. ${ }^{40}$

years, later confirmed at several judiciary proceedings.

${ }^{39}$ Here is the Spanish writer Antonio Muñoz Molina, considering a related possibility; he is commenting on Mário de Carvalho's novel A Casa Magenta in his weekly El País column (“Descubrimiento de Mário de Carvalho”, 4/5/2019, my translation): "In $A$ Sala Magenta there are sagacious and ironic, even cruel, portraits of characters of a fauna between intellectual and mundane that are repeated in any city of any country, with the usual doses of meanness and imposture, of vanity, of pure pretentious nonsense. I imagine that a Portuguese reader will believe he recognizes in them, with that satisfaction that malevolence provokes, real models, and will read other names under those which they have in the novel. I have the freedom to see them as creatures of a novelist's imagination. They exist for me exclusively on the basis of the words of which they are made".

${ }^{40}$ Cases like de Vigan's novel mentioned above, fn. 28 are further good real examples, involving the novels themselves. A novel with the same title is a fictional character; on an interpretation, this is a surrogate for the very same real novel we are reading, hence it allows for importation of facts about it not mentioned in the novel. On another, this is a casual coincidence, even though we are playfully required to pay attention to the similitudes. This is my own take on Walton's (1990: 113) distinction between representing and referring, which Friend (this volume, §6) appears to assume in her discussion of Swift's character Flimnap vis-à-vis Walpole; Walton discusses the analogous case of Leibniz-Dr. Pangloss in Voltaire's Candide. Like the Vincent Benét's story, the fictions admit an interpretation allowing importation, and another disallowing it, even though readers are expected to keep the resemblances in mind for pragmatic effects, satire or parable. A similar view handles the distinction between the "playful postmodern- 
These examples allow me to press the explanatory advantage I claim for E, which is just that it allows us to easily make sense of intermediate cases. War and Peace has an official and an unofficial interpretation, along the suggested lines. Both are about Bezukhov, a fictional character. The unofficial interpretation, however, is also thereby about Tolstoy - the fictional Bezukhov being a surrogate for it, in interpretations available to those in the knowing of the required matches (thanks to literary critics and Wikipedia, now many of us). The same, mutatis mutandis, applies to 'Napoleon', as it figures in the fiction; it is just that with respect to this case the official interpretation is the one entitling importation and exportation. Both share a purely fictional core, but only one is thereby about the real Napoleon, allowing importation and hence prescribing imagining a more detailed fictional world; the other merely invites comparing him to its fictional counterpart. Vincent Benét's short story, on the other hand, has two equally official interpretations. ${ }^{41}$ This availability of a purely fictional interpretation is the "core of truth" I find in Riffaterre's quote ( $§ 1)$. I'll leave it as a challenge for supporters of NE to come up with an alternative, equally explanatory account. ${ }^{42}$

\section{The uniformity argument against E}

Friend provides a nice elaboration of what I take to be the argument for NE and against $\mathrm{E}$ with the strongest intuitive pull, which I'll call

ist" and "ignorant author" variants of The Ferrante Affair that Friend also discusses (ibid). Both have the same interpretation, disallowing importation of the characters' real identity; but only the former intends the reader to attend to it.

${ }^{41}$ Walton concurs with the possibility I envisage: "Readers can, if they choose, ignore the fact that the author is making claims about the real world and concern themselves only with the narrator and what happens 'in the fictional world'," (ibid., 80). He (ibid., 108) points out the significance of having names in fiction "referring" (at least in pretense) to merely fictional characters, even when the fiction is (at least on some acceptable readings) about a real object. Cp. his distinction between a fiction matching and representing an object.

${ }^{42}$ Motoarca (2014: 1042-4) has a similar argument, based on cases of satirical allusion. 
the Uniformity Argument as a descriptively adroit label. ${ }^{43}$ She had appealed to it in her previous work on these matters, Friend (2000), and Parsons (1980: 57-8) offered an earlier version. Parsons says that there is "no difference in the referential situation" that he can see in these transitions:

(i) Telling a lie about Jimmy Carter

(ii) Telling a lie about Carter which is very long (e.g., book length)

(iii) Making up a story about Carter which is not intended to deceive anyone, and which contains falsehoods

(iv) Writing a work of fiction in which Carter is a character

As Motoarca (2014: 1049) points out, this version of the argument explicitly relies on the aboutness intuitions discussed in the previous section. We thus already have a good reply to it: to be sure, there need be no difference in aboutness between the lie in (ii) and the fiction in (iii) — which is the problematic step for present purposes. But this leaves open whether there is a difference in the semantic behavior of 'Jimmy Carter' in the lie and in the story. Remember our motto: aboutness is intuitive and malleable; singular reference is theoretical and constrained.

Friend's (this volume) new way of elaborating the argument stresses the point really at stake, which is whether there is a semantic difference at that step in the transition. She considers a history work on Richard III by Alison Weir, The Princes in the Tower. She reminds us the reasons for a direct reference view about the contribution there of 'Richard' in simple sentences, and she sums up reasonable conditions given which Weir was able to refer to Richard III by means of it. Then she argues that Shakespeare met those conditions in using the same name to portray Richard III in The Tragedy of King Richard the Third. This should suffice, she urges, for us to take his uses of 'Richard' there exactly as we understand those by Weir.

My reply to this is that, even if one meets conditions to refer to Richard III, and does it when one makes assertions about that king

${ }^{43}$ Mole (2009: 483) also endorses a succinct version. 
using simple sentences, there are good theoretical reasons, outlined above, to question that this is how the expression behaves when one uses it in some attitude ascriptions. Davidson's Semantic Innocence might be prima facie intuitively very plausible; in fact, the intuitions in question are, I understand, the very same that the Uniformity Argument mobilizes. But there are very serious theoretical considerations against it, and they suffice to defeat whatever force those intuitions might have. ${ }^{44}$

Let me develop what I have already said above on this. I grant the direct reference view about the contribution of 'Starnone' to the content of standard assertoric utterances of (8). They are made with the goal of providing information, whose correctness only depends on how things stand with Starnone-independently of how he is identified. Loar (1976) convincingly showed that understanding 'Starnone' in such utterances requires more than identifying the referent; but, as I argued (García-Carpintero 2000; cf. Buchanan 2014), a presuppositional view about the role of the additional identificatory material that must be grasped for full understanding allows us to account for Loar's examples and stick to the intuition of direct reference about asserted content.

However, such powerful direct reference intuitions concerning the contribution of 'Starnone' to a straightforward assertoric utterance of (8), and the underlying judgment, don't transfer in the immediate way the Uniformity Argument assumes to textual and paratextual uses of the same sentences. In such uses the sentence is not primarily used to impart information about the Italian writer,

${ }^{44}$ Some theorists who accept a broadly Fregean view on the truth-conditions of attitude ascriptions nominally preserve Semantic Innocence/Uniformity by having the shifted contribution of terms in attitude ascriptions to be triggered by a "hidden indexical", or by the attitudinal verb. It should be clear that this is irrelevant for present purposes: here those views count as different ways of rejecting SI/Uniformity, whether this is explained by a shift in the semantic behavior of the name itself, by the contribution of a (perhaps hidden) in the pretense operator, or by an otherwise triggered contextual shift. Putting aside such semantic details, most formal semanticists would I think agree that Friend's aspiration for "a unified account of proper names" (this volume, $\S \S 3,5$ ) cannot be fulfilled: names in simple and embedded sentences behave differently, however this is explained. My argument has proceeded by assimilating textual uses of names to their uses embedded in intensional contexts; cf. also Orlando 2017. 
but to tell us instead what and how we are supposed to imagine in order to fulfil the specifications of a fiction. There are solid theoretical reasons to think that the differences in the speech acts and in the underlying attitudes are relevant here.

In addition to those presented above, I have in mind deeper reasons like the following. There are serious debates about whether the content of perceptual experiences (assuming they have one) is singular, or it is merely general, and whatever singularity experiences may have accrues to them from other mental states in their cognitive environment. I myself disagree with this; but other philosophers have taken a similar line about the imagination, and here I am much more sympathetic, for reasons that the late Fabian Dorsch (2016: 105-6) sums up here:

I am quite sympathetic with the idea that perception is particular, but imaginative experience is not ... In my view, imaginative experiences become referential in a similar way as depictions. Because how they present things as being does not nomologically depend on how some real things look like (e.g. even if we intend to visualize or paint a particular person, say, we are free to choose to 'alter' the appearance of the person when visualizing or painting her), they may actually lack any referent ... This illustrates that being a non-perceptual visual experience is not sufficient for referentiality. What is missing is some factor external to the occurrence of non-perceptual visual presentation - such as an additional thought or intention of the subject or artist concerned.

Views like this are compatible with the point that the imagination is (even normally, in fulfilment of its teleological function) used to find out useful facts about the world. As Dorsch suggests, even if the imagination lacks constitutively singular contents, it might acquire them from the cognitive context in which it is deployed. Kind (2018: 239-44) and Langland-Hassan (2015: 676) advance similar views. It is in this way that we could explain Friend's example of imagining your friend, whom you are seeing wearing a hat (this volume, §5): the singularity comes from perception, not from the imagining itself. This is in line with the reply I gave in the previous section to the aboutness argument. Even if fictions including 'Napoleon' are primarily about a surrogate of the military genius, we can still explain how some of those fictions allow for importation and exportation of facts about him. It is in this way that my imaginings concerning 
Napoleon when reading War and Peace "seem rather to be directed at a particular individual" (Friend, this volume §6). One last time: aboutness is cheap, singular reference not that much.

Of course, this view might be wrong. But its prima facie availability suffices, I believe, to defeat the Uniformity Argument. It shows that, by itself, it doesn't establish NE.

\section{Conclusion}

In this paper I have critically discussed views about how real names work in fictional discourse. I have contrasted the exceptionalist view that they don't work there as in ordinary assertions of simple subject-predicate sentences, with a conflicting non-exceptionalist view. I have shown that there are views sufficiently close to traditional descriptivist frameworks, like them partially motivated by facts about fictional names, which resist contemporary arguments for NE. They considerably improve on extant exceptionalist accounts in addressing the usual arguments for $\mathrm{NE}$ and in furnishing us with compelling arguments for $\mathrm{E}^{45}$

Manuel García-Carpintero BIAP/LOGOS-Departament de Filosofia Universitat de Barcelona m.garciacarpintero@ub.edu

\section{References}

Alward, Peter. 2011. Description, disagreement, and fictional names. Canadian Journal of Philosophy 41(3): 423-48.

${ }^{45}$ Financial support was provided by the DGI, Spanish Government, research project FFI2016-80588-R and FFI2016-81858-REDC, the award ICREA Academia for excellence in research, 2018, funded by the Generalitat de Catalunya, and the European Union's Horizon 2020 Research and Innovation programme under Grant Agreement no. 675415, Diaphora. This work received helpful comments from audiences at talks and conferences in Barcelona, Bratislava, Budapest, Ciudad de México, LA, Lisbon, Munich, Prague, Valencia and Wollongong; and from Stacie Friend, Daniela Glavaničová, Mario Gómez-Torrente, Fred Kroon, Stefano Predelli, Enrico Terrone, Jordi Valor, Alberto Voltolini, Lee Walters, and Zsofia Zvolenszky. Thanks also to Michael Maudsley for the grammatical revision. 
Asher, Nicholas. 2006. Things and their aspects. Philosophical Issues 16: 1-23. Bertolet, Rod. 1984. On a fictional ellipsis. Erkenntnis 21: 189-94.

Boër, S.E.; and Lycan, W. 1986. Knowing Who. Cambridge, Mass.: MIT Press. Bonomi, Andrea. 2008. Fictional contexts. In Perspectives on Context, edited by P. Bouquet, L. Serafini and R. Thomason. Stanford: CSLI Publications, 213-48.

Brock, S.; and Everett, A. 2015. Fictional Objects. Oxford: Oxford University Press.

Buchanan, Ray. 2014. Reference, understanding, and communication. Australasian Journal of Philosophy 92(1): 55-70.

Burge, Tyler. 2009. Five theses on de re states and attitudes. In The Philosophy of David Kaplan. Edited by J. Almog and P. Leonardi. Oxford: Oxford University Press, 246-324.

Chalmers, David. 2011a. Propositions and attitude ascriptions: a Fregean account. Noûs 45(4): 595-639.

Chalmers, David. 2011b. Verbal disputes. Philosophical Review 120(4): 515-66.

Currie, Gregory. 1990. The Nature of Fiction. Cambridge: Cambridge University Press.

Devitt, Michael. 1981. Designation. Cambridge, MA: MIT Press.

Dorsch, Fabian. 2016. Knowledge by imagination- - how imaginative experience can ground factual knowledge. Teorema 35(3): 87-116.

Everett, Anthony. 2013. The Nonexistent. Oxford: Oxford University Press.

Everett, A.; and Schroeder, T. 2015. Ideas for stories. In Fictional Objects. Edited by S. Brock and A. Everett. Oxford: Oxford University Press, 275-93.

Friend, Stacie. 2000. Real people in unreal contexts. In Empty Names, Fiction and the Puzzles of Non-existence. Edited by A. Everett and T. Hofweber, Stanford: CSLI, 183-203.

Friend, Stacie. 2007. Fictional characters. Philosophy Compass 2(2): 141-56.

Friend, Stacie. 2011. The great beetle debate: a study in imagining with proper names. Philosophical Studies 153: 183-211.

Friend, Stacie. 2012. Fiction as a genre. Proceedings of the Aristotelian Society 92: 179-208.

Friend, Stacie. 2014. Notions of nothing. In Empty Representations: Reference and Non-Existence. Edited by M. García-Carpintero and G. Martí. Oxford: Oxford University Press, 307-32.

Friend, Stacie. 2017. Elucidating the truth in criticism. Journal of Aesthetics and Art Criticism 75: 387-99.

García-Carpintero, Manuel. 1998. Indexicals as token-reflexives. Mind 107: 529-63.

García-Carpintero, Manuel. 2000. A presuppositional account of referencefixing. Journal of Philosophy 97(3): 109-47.

García-Carpintero, Manuel. 2006a. Recanati on the semantics/pragmatics distinction. Crítica 38: 35-68.

García-Carpintero, Manuel. 2006b. Two-dimensionalism: a neo-Fregean interpretation. In Two-Dimensional Semantics. Edited by M. García- 
Carpintero and J. Macià. Oxford: Oxford University Press, 181-204.

García-Carpintero, Manuel. 2007. Fiction-making as an illocutionary act. Journal of Aesthetics and Art Criticism 65: 203-16.

García-Carpintero, Manuel. 2010a. Fictional singular imaginings. In New Essays on Singular Thought. Edited by Robin Jeshion. Oxford: Oxford University Press, 273-99.

García-Carpintero, Manuel. 2010b. Fictional entities, theoretical models and figurative truth. In Beyond Mimesis and Convention-Representation in Art and Science. Edited by R. Frigg, and M. Hunter. Springer, 139-68.

García-Carpintero, Manuel. 2013. Norms of fiction-making. British Journal of Aesthetics 53: 339-57, DOI: 10.1093/aesthj/ayt021.

García-Carpintero, Manuel. 2015. Is fictional reference rigid? Organon F 22: 145-68.

García-Carpintero, Manuel. 2016. To tell what happened as invention: literature and philosophy on learning from fiction. In Literary Studies and the Philosophy of Literature: New Interdisciplinary Directions. Edited by Andrea Selleri and Philip Gaydon. London: Palgrave Macmillan, 123-47.

García-Carpintero, Manuel. 2017. The Mill-Frege theory of proper names. Mind doi:10.1093/mind/fzx010.

García-Carpintero, Manuel. 2018. Co-identification and fictional names. Philosophy and Phenomenological Research Online First, DOI: 10.1111/ phpr.12552.

García-Carpintero, Manuel. 2019a. State of the art: semantics of fictional terms. Teorema.

García-Carpintero, Manuel. 2019b. Assertions in fictions: an indirect speech act account. Grazer Philosophische Studien.

García-Carpintero, Manuel. 2019c. On the nature of fiction-making: Grice or Austin? British Journal of Aesthetics, doi: 10.1093/aesthj/ayy054.

García-Carpintero, Manuel. 2019d. Normative fiction-making and the world of the fiction. Journal of Aesthetics and Art Criticism 77(3): 267-79, DOI: 10.1111 /jaac. 12660 .

García-Carpintero, Manuel. 2020. Referential indeterminacy in fiction. Journal of Applied Logic 7(2): 177-90.

Gendler, Tamar Szabó. 2000. The puzzle of imaginative resistance. Journal of Philosophy 97(2): 55-81.

Gómez-Torrente, Mario. 2019. Roads to Reference. An Essay on Reference-fixing in Natural Language. Oxford: Oxford University Press.

Grzankowski, Alex. 2018. A relational theory of non-propositional attitudes. In Non-Propositional Intentionality. Edited by A. Grzankowski and M. Montague, Oxford: Oxford University Press, 134-51.

Hoek, Daniel. 2018. Conversational exculpature. Philosophical Review 127(2): 151-96.

Kaplan, David. 1969. Quantifying in. In Words and Objections. Edited by D. Davidson and J. Hintikka. Dordrecht: D. Reidel Publishing Company, $178-214$. 
Kaplan, David. 1989. Demonstratives. In Themes from Kaplan. Edited by J. Almog, J. Perry and H. Wettstein. Oxford: Oxford University Press, 481-563.

Kind, Amy. 2018. How imagination gives rise to knowledge. In Perceptual Memory and Perceptual Imagination. Edited by Fiona Macpherson and Fabian Dorsch. Oxford: Oxford University Press, 227-46.

Kot'átko, Petr. 2010. Who is who in the fictional work. In Fictionality-PossibilityReality. Edited by P. Kotátko, M. Pokorný and M. Sabatés. Aleph, Bratislava, 89-102.

Kripke, Saul. 1980. Naming and Necessity. Cambridge, Mass.: Harvard University Press.

Kripke, Saul. 2011. Vacuous names and fictional entities. In his Philosophical Troubles. Oxford: Oxford UP, 52-74 (based on a talk given in 1973).

Kripke, Saul. 2013. Reference and Existence. Oxford: Oxford University Press (based on the John Locke lectures originally delivered in 1973).

Kroon, Frederick. 1994. A problem about make-believe. Philosophical Studies 75: 201-29.

Kroon, Frederick. 2004. Descriptivism, pretense, and the Frege-Russell problems. Philosophical Review 113: 1-30.

Kroon, Frederick. 2005. Belief about nothing in particular. In Fictionalism in Metaphysics. Edited by M. Kalderon. Oxford: Oxford U.P., 178-203.

Kroon, Fred; and Voltolini, Alberto. 2016. Fiction. The Stanford Encyclopedia of Philosophy (Winter 2016 Edition). Edited by Edward N. Zalta. URL = https://plato.stanford.edu/archives/win2016/entries/fiction/.

Lamarque, Peter. 2014. The Opacity of Literature, Oxford: Oxford University Press.

Lamarque, P.; and Olsen, S. H. 1994. Truth, Fiction and Literature. Oxford: Clarendon Press.

Langland-Hassam, Peter. 2015. Imaginative attitudes. Philosophy and Phenomenological Research 90: 664-86.

Lewis, David. 1978. Truth in fiction. American Philosophical Quarterly 15: 37-46. Reprinted with postscripts in D. Lewis, Philosophical Papers, vol. 1, 261-80. Oxford: Oxford University Press, 1983, from which I quote.

Loar, Brian. 1976. The semantics of singular terms. Philosophical Studies 30: 353-77.

Ludlow, Peter. 2006. From Sherlock Holmes and Buffy to Klingon and Norrathian Platinum Pieces: pretence, contextualism, and the myth of fiction. Philosophical Issues 16: 162-83.

Maier, Emar. 2010. Presupposing acquaintance: a unified semantics for de dicto, de re and de se belief reports. Linguistics and Philosophy 32(5): 429-74.

Maier, Emar. 2016. Attitudes and mental files in discourse representation theory. Review of Philosophy and Psychology 7: 473-90.

Maier, Emar. 2017. Fictional names in psychologistic semantics. Theoretical Linguistics 43(1-2): 1-45.

Manning, Luke. 2014. Real representation of fictional objects. Journal of 
Aesthetics and Art Criticism 72(1): 13-24.

Mole, Christopher. 2009. Fiction's ontological commitments. The Philosophical Forum 40(4): 473-88.

Motoarca, Ioan-Radu. 2014. Fictional surrogates. Philosophia 42: 1033-53.

Motoarca, Ioan-Radu. 2018. Are fictional characters and literary works ontologically on a par? Pacific Philosophical Quarterly 99: 596-611. DOI: 10.1111 /papq. 12182 .

Orlando, Eleonora. 2017. Files for fiction. Acta Analytica 32: 55-71.

Parsons, Terence. 1980. Nonexistent Objects. New Haven: Yale U.P.

Perry, John. 2009. Directing intentions. In The Philosophy of David Kaplan. Edited by J. Almog and P. Leonardi. Oxford: Oxford University Press, 187-201.

Perry, John. 2012. Reference and Reflexivity. 2nd Edition. Stanford: CSLI Publications.

Pickel, Bryan. 2015. Variables and attitudes. Nô̂s 49(2): 333-56.

Predelli, Stefano. 1997. Talk about fiction. Erkenntnis 46: 69-77.

Predelli, Stefano. 2002. 'Holmes' and Holmes - a Millian analysis of names from fiction. Dialectica 56(3): 261-79.

Predelli, Stefano. 2017. Proper Names: A Millian Account. Oxford: Oxford University Press.

Predelli, Stefano. 2020. Fictional Discourse. Oxford: Oxford University Press.

Recanati, François. 2000. Oratio Obliqua, Oratio Recta. Cambridge: MIT Press.

Recanati, François. 2018. Fictional, metafictional, parafictional. Proceedings of the Aristotelian Society 118: 25-54.

Reimer, Marga. 2005. The ellipsis account of fiction-talk. In Ellipsis and Nonsentential Speech. Edited by R. Elugardo and R. Stainton. Dordrecht: Springer, 203-15.

Riffaterre, Michael. 1990. Fictional Truth. Baltimore: John Hopkins University Press.

Russell, Bertrand. 1903. On meaning and denotation. In The Collected Papers of Bertrand Russell, Volume 4: Foundations of Logic, 1903-05. Edited by Alasdair Urquhart. Routledge: London, 1994, 324-58.

Sainsbury, Mark. 2018. Thinking about Things. Oxford: Oxford University Press,.

Salmon, Nathan. 1998. Nonexistence. Noûs 32: 277-319.

Salmon, Nathan. 2004. The good, the bad, and the ugly. In Descriptions and Beyond. Edited by M. Reimer and A. Bezuidenhout. Oxford: Oxford University Press.

Schiffer, Stephen. 2003. The Things We Mean. Oxford: Clarendon Press.

Soames, Scott. 2002. Beyond Rigidity. New York: Oxford U.P.

Stalnaker, Robert. 197. Assertion. In Syntax and Semantics 9. Edited by P. Cole. New York: Academic Press, 315-32.

Stokke, Andreas. (Forthcoming.) Fictional names and individual concepts. Synthese.

Szabó, Zoltan G. 2003. On qualification. Philosophical Perspectives 17: 385-414.

Thomasson, Amie L. 1999. Fiction and Metaphysics. Cambridge: Cambridge U.P. 
Thomasson, Amie L. 2003. Speaking of fictional characters. Dialectica 57: 205-23.

Thomasson, Amie L. 2010. Fiction, existence and indeterminacy. In Fictions and Models: New Essays. Edited by John Woods. Munich: Philosophia Verlag, 109-48.

van Inwagen, Peter. 1977. Creatures of fiction. American Philosophical Quarterly 14: 299-308.

Voltolini, Alberto. 2006a. How Ficta Follow Fiction. A Syncretistic Account of Fictional Entities. Dordrecht: Springer.

Voltolini, Alberto. 2006b. Fiction as a base of interpretation contexts. Synthese 153: 23-47.

Voltolini, Alberto. 2013. Probably the Charterhouse of Parma does not exist, possibly not even that Parma. Humana-Mente Journal of Philosophical Studies 25: 235-61.

Voltolini, Alberto. 2016. The nature of fiction/al utterances. Humana-Mente Journal of Philosophical Studies 25: 28-55.

Walters, Lee. 2017. Fictionality and imagination, revisited. Journal of Aesthetics and Art Criticism 75(1): 15-21.

Walters, Lee. (ms.) Fictional names.

Walton, Kendall. 1990. Mimesis and Make-Believe. Cambridge, Mass.: Harvard U.P.

Williamson, Timothy. 1996. Knowing and asserting. Philosophical Review 105: 489-523; included with some revisions as chapter 11 of his Knowledge and Its Limits, Oxford UP, New York, 2000, from which I quote.

Wolterstorff, Nicholas. 1980. Works and Worlds of Art. Oxford: Clarendon Press.

Yablo, Stephen. 2001. Go figure: a path through fictionalism. Midwest Studies in Philosophy 25. Edited by Peter A. French and Howard K. Wettstein. Oxford: Blackwell, 72-102.

Yablo, Stephen. 2014a. Aboutness. Princeton: Princeton University Press.

Yablo, Stephen. 2014b. Carnap's paradox and easy ontology. Journal of Philosophy $111(9 / 10) 470-501$. 